\title{
Prospective ESL/EFL Teachers' Perceptions towards Writing Poetry in a Second Language: Difficulty, Value, Emotion, and Attitude
}

\author{
Fang-Yu Liao ${ }^{*}$ * (D) \\ ${ }^{a}$ Indiana University of Pennsylvania, Indiana PA 15705, U.S.A.
}

Received 25 October 2016 | Received in revised form 8 May 2017 | Accepted 28 October 2017

\begin{abstract}
The study aims to explore how 18 M.A. TESOL students, who are prospective or experienced ESL/EFL teachers, perceive poetry writing in a second language. A qualitative interview-based design was utilized. Following Iida's (2012a) analytical framework in examining EFL students' perceptions toward writing haiku in English, this current study investigates 18 prospective ESL/EFL teachers' perspectives through the lens of difficulty, value, emotion, and attitude. In order to validate the coding of the interviews, the intraclass correlation coefficient (ICC) test was computed among three interview coders including the primary researcher, which yields a great agreement rate at .86. The results indicate that while these prospective ESL/EFL teachers understand writing poetry in a second language involves various difficulties, they acknowledge the values of utilizing poetry writing in second language classrooms. The results also show that writing poetry in a second language contains both positive and negative emotions, but positive ones are more frequently addressed. Most importantly, the data suggests that writing poetry in a second language is considered as an applicable practice in ESL/EFL language classrooms.

(C) 2018 EJAL \& the Authors. Published by Eurasian Journal of Applied Linguistics (EJAL). This is an open-access article distributed under the terms and conditions of the Creative Commons Attribution license (CC BY-NC-ND) (http://creativecommons.org/licenses/by-nc-nd/4.0/).
\end{abstract}

Keywords: Poetry writing; ESL context; perceptions; M.A. TESOL; language teaching

\section{Introduction}

Researchers have stated that ESL students tend to see their motivation for learning English as becoming native-like (Fernsten, 2008; Kramsch, 2003; McKay, 2009). That is, ESL students fail to have the ownership of English (Pennycook, 1996) and see themselves as outsiders compared to the native speakers (Fernsten, 2008). In addition, Iida (2008) mentioned that the focus of the writing classes in EFL contexts is mainly on practical writing skills and grammatical accuracy, and he further stated that students' voice in their writing should also be taken into consideration. In other words, the writing classes for ESL/EFL students mostly emphasize grammatical and structural aspects; therefore, it implies that in the ESL/EFL writing classes, the

\footnotetext{
* Corresponding author name. Tel.: +1-626-262-1520

E-mail address: fangyuliao20@gmail.com

http://dx.doi.org/...
} 
students are likely to lose their opportunities to express themselves with their thoughts and to acknowledge themselves as multilingual writers.

In order to humanize language classrooms for ESL/EFL students to express themselves, Hanauer (2011) proposed a meaningful literacy learning approach through writing poetry. Many scholars have studied the use of poetry writing in ESL/EFL classrooms: (a) the use of poetry writing practice in ESL/EFL classrooms (see Garvin, 2013; Hanauer, 2011; Tin, 2010), (b) the connection of emotion in writing poetry and L1/L2 languages (see Chamcharatsri, 2013), (c) the values of poetry writing (see Iida, 2012b), (d) the characteristics of ESL/EFL poetry (see Hanauer, 2010; Iida, 2012b, 2016a), and (e) the poetic identity and voice in ESL/EFL poems (see Hanauer, 2010, 2014; 2015; Iida, 2016b; Liao, 2016). While these studies have contributed to the understandings and pedagogical ideas on the topic of poetry writing in a second language, few empirical studies focus on examining how ESL/EFL students perceive writing poetry in their second language (see Iida, 2012a; Liao \& Roy, 2017). Iida's qualitative study (2012a) examined EFL undergraduate students' perceptions of haiku writing while Liao and Roy's quantitative study (2017) explored EFL undergraduate students' desire to write poetry in a second language. However, the discussion of ESL/EFL advanced students' or teachers' perceptions remains absent in current literature. In order to fill this gap, this study aims to answer the following research question: how do prospective ESL/EFL teachers perceive poetry writing in a second language?

\subsection{Studies on Writing Poetry in a Second Language}

As presented earlier, Hanauer (2011) envisioned that meaningful literacy learning is a way to humanize language classrooms through teaching poetry writing in a second language. Poetic genres were logical choices for humanizing the language classroom given how poetry has been defined. Hanauer (2004) defined poetry as "a literacy text that presents the experiences, thoughts, and feelings of the writer through self-referential use of language that creates for the reader and writer a new understanding of the experience, thought, or feeling expressed in the text" (p. 10). This definition invites a more open, liberating, and accessible concept toward poetry because it emphasizes the understandings of one's experiences and feelings. Additionally, the "self-referential use of languages" embraces one's diverse resources including textual, linguistic, multilingual, cultural, aural, spatial, and visual modes. Thus writing poetry in a second language liberates ESL/EFL students from connecting writing in English with meeting grammatical and structural accuracy; it invites them to value their multiple resources and to consider writing as a pleasant process.

While many scholars have touched upon the research inquiry of second language poetry writing, at this point in time, there are limited empirical studies on poetry writing in ESL/EFL contexts (see Chamcharatsri, 2013; Garvin, 2013; Hanauer, 2010, 2015; Iida, 2012a, 2012b, 2016a, 2016b; Liao, 2016; Tin, 2010). The contexts of these 
studies were in various countries, including Thailand, China, U.S.A., Japan, and Indonesia. This shows an increasing interest in utilizing poetry writing in both ESL and EFL contexts. Among these studies, many have addressed the value of writing poetry in a second language: (a) re-experiencing the moments in one's poems and enabling the readers to connect others' experiences with theirs (Garvin, 2013; Hanauer, 2010, 2011, Iida, 2016b), (b) expressing emotion (Chamcharatsri, 2013), (c) self-discovery (Garvin, 2013; Hanauer 2010, 2011, Liao, 2016), (d) transferability of skills to prose writing (Iida, 2012b), and (e) linguistic development (Hanauer, 2010; Iida, 2012b; Tin, 2010). From these standpoints, writing poetry is considered as a process that is free, expressive, transformational, and enjoyable for L2 student writers. This contributes to reasons why poetry should be included as an alternative approach in the ESL/EFL language classrooms.

If we acknowledge the potentials of utilizing poetry writing in ESL/EFL language classrooms, some may be curious about what student poetry would look like. Scholars have addressed the inquiry on the characteristics of ESL/EFL poetry. Hanauer (2010) conducted a longitudinal study to investigate 81 ESL students with the total corpus of 844 poems from the year of 2003 to 2009 in the U.S. With this rich data, Hanauer discussed the characteristics of second language poetry through corpus analysis. Iida (2012b) compared his haiku corpus data from 20 EFL students in Japan with Hanauer's (2010) ESL poetry data. Iida (2016a) further analyzed another corpus of 773 poems about an earthquake in the context of Japan. These studies examined specific characteristics of their poetry corpus, including word numbers, linguistic features, word frequency band and percentage, high frequency words/usages, and percentage of words from total word count according to affective processes. The results of their data showcased that ESL/EFL poetry/haiku are usually short, descriptive, direct, emotional, and personal.

Going beyond linguistic characteristics, there are scholars who tackled the inquiry on what ESL/EFL students compose in their poetry in terms of the content level (see Garvin, 2013; Hanauer, 2010; Iida, 2016a). In Garvin's study, 75 EFL Chinese students were guided to write three poems based on a "personal memory of a famous person, place, or object/event in Chinese history and culture" (p. 82). Although students were instructed to connect the content of the poetry to Chinese history and culture, Garvin's data showed that EFL students in her study composed poems about various places, people, and events relating to China. In Hanauer's study, 81 ESL students were guided to write poems about any life experiences as their topics, and he reported that these students had the tendency to write about study aboard experiences with some overlapping themes, such as homesickness, experiencing American students, or emotional response to classroom experiences. In Iida's study, 78 EFL Japanese students were instructed to write a poetry book to reflect their experiences of the earthquake that happened in Japan in 2011. The results showed 11 emerging themes, such as the moment when the earthquake occurs, powerfailure/Blackout, or hope, prayer and positive action to evacuees. These three studies 
provide insight on what ESL/EFL students compose in their poems, but additional empirical studies are needed to address more diverse contexts and groups.

Furthermore, some researchers emphasize understanding the poetic identity and voice in second language poems. Studies were conducted to focus on one case study to explore one specific personal experience: (a) one ESL Japanese student's parental divorce experience (Hanauer, 2010), (b) one EFL Myanmarese student's study abroad experience in Japan (Iida, 2016b), and (c) one ESL Chinese student's experience with a father-son relationship (Liao, 2016). These three studies demonstrated that ESL/EFL students are capable of building their personal voices when writing poetry in a second language through a qualitative perspective. Relatedly, through a quantitative approach, Hanauer (2015) conducted a study to measure voice in second language poems. He utilized the design of human raters to see whether they can distinguish between poems written by different second language student writers and the computational analysis of the poems to see if each student poem had different characters. He concluded that ESL/EFL students have a personalized voice in their poems. These studies establish the acknowledgement that ESL/EFL students can construct personal voice when writing poetry in a second language through both a qualitative and quantitative lens.

Last, Iida (2012a) reported 20 EFL students' perceptions toward haiku writing. In order to explore those students' perceptions, he looked at four themes: difficulty, value, emotion, and attitude. The data of his study showed that EFL haiku is a valuable approach to develop students' self-expression in finding a voice in writing as well as to improve students' linguistic knowledge in a second language. On the other hand, Liao and Roy (2017) examined the factors that contribute to EFL undergraduate students' desire to write poetry in a second language. Through the statistical analysis, we found the more extensive exposure to great literature may contribute to an idealistic notion of poetry. Our survey data also showed L2 English literature students perceive lower confidence and desire to write poetry compared to L2 engineering students, which strengthens the idea that English literature can have a detrimental effect that leads to L2 students' diffidence and reluctance in writing poetry. Although both aforementioned studies provide insights on how EFL students perceive and reflect on writing poetry in a second language, a more comprehensive picture would emerge through inquiry into how prospective ESL/EFL teachers understand poetry writing. To provide this aspect of understanding, this current study aims to investigate perceptions of 18 prospective ESL/EFL teachers toward writing poetry in a second language.

\section{Methodology}

\subsection{Participants}

All participants are M.A. TESOL students who studied in western Pennsylvania of the United States. The rationale of choosing M.A. TESOL multilingual students is 
that they are teachers or prospective teachers, so it is worthy of knowing their standpoints and considerations about writing poetry in a second language. Table 1 shows the background information about each participant.

\subsection{Data collection}

The recruitment of subjects included two steps. First, the recruitment was done through emails. The informed consent form was provided as an attachment. The places and time of the meeting were discussed with participants, and at the first meeting, they were asked again about their consent to participate.

As for the second part of the recruitment process, the participants were recruited from one of the M.A. TESOL classes with the permission of the class instructor, which had been obtained via email. In order to enable them to understand the overview of the study, a 20-minute presentation was given to the class regarding the research and protocols. After the presentation, I contacted the students via the contact information they provided in that class. Those students were asked if they would like to participate in the research study. Participants were informed of the nature of the research and invited to request further information or the final research product.

Semi-structured interviews were utilized in this study to know each participant's historical backgrounds about their English writing experiences and to understand their perspectives about poetry writing (see Appendix A). The interviews were audiorecorded and transcribed, and it lasted approximately 40 minutes.

Table 1. Participants' Background Information (N:18)

\begin{tabular}{|c|c|c|c|c|c|}
\hline Name & Gender & Country & First Languages & Poetry Writing Experiences & $\begin{array}{l}\text { Years of } \\
\text { Experiencing } \\
\text { Writing Instructions }\end{array}$ \\
\hline Amanda & Female & China & Mandarin & None & 10 years \\
\hline Amir & Male & Niger & $\begin{array}{l}\text { French \& Local } \\
\text { Dialect }\end{array}$ & $\begin{array}{l}\text { Personal interests and one in- } \\
\text { class activity }\end{array}$ & 8 years \\
\hline Bob & Male & $\begin{array}{l}\text { Saudi } \\
\text { Arabia }\end{array}$ & $\begin{array}{l}\text { Arabic \& Local } \\
\text { Dialect }\end{array}$ & $\begin{array}{l}\text { One poetic autoethnography } \\
\text { assignment }\end{array}$ & 15 years \\
\hline Charles & Male & $\begin{array}{l}\text { Saudi } \\
\text { Arabia }\end{array}$ & $\begin{array}{l}\text { Arabic \& Local } \\
\text { Dialect }\end{array}$ & $\begin{array}{l}\text { One poetic autoethnography } \\
\text { assignment }\end{array}$ & 17 years \\
\hline Ember & Female & China & $\begin{array}{l}\text { Mandarin \& } \\
\text { Local Dialect }\end{array}$ & $\begin{array}{l}\text { One poetic autoethnography } \\
\text { assignment and personal interests }\end{array}$ & 11 years \\
\hline Enzo & Male & $\begin{array}{l}\text { Saudi } \\
\text { Arabia }\end{array}$ & $\begin{array}{l}\text { Arabic \& Local } \\
\text { Dialect }\end{array}$ & $\begin{array}{l}\text { One poetic autoethnography } \\
\text { assignment }\end{array}$ & 12 years \\
\hline Grace & Female & Indonesia & $\begin{array}{l}\text { Indonesian \& } \\
\text { Local Dialect }\end{array}$ & $\begin{array}{l}\text { One poetic autoethnography } \\
\text { assignment }\end{array}$ & 13 years \\
\hline Iris & Female & Indonesia & $\begin{array}{l}\text { Indonesian \& } \\
\text { Local Dialect }\end{array}$ & One in-class activity & 9 years \\
\hline Joseph & Male & Iraq & $\begin{array}{l}\text { Arabic \& } \\
\text { Local Dialect }\end{array}$ & None & 8 years \\
\hline Joy & Female & Ivory Coast & $\begin{array}{l}\text { French \& } \\
\text { Local Dialect }\end{array}$ & $\begin{array}{l}\text { One poetic autoethnography } \\
\text { assignment }\end{array}$ & 13 years \\
\hline
\end{tabular}




\begin{tabular}{|l|l|l|l|l|l|}
\hline Kelly & Female & China & Mandarin & $\begin{array}{l}\text { One poetic autoethnography } \\
\text { assignment }\end{array}$ & 15 years \\
\hline Liz & Female & China & $\begin{array}{l}\text { Mandarin \& } \\
\text { Local Dialect }\end{array}$ & $\begin{array}{l}\text { Personal interests and one in- } \\
\text { class activity }\end{array}$ & 8 years \\
\hline Mike & Male & Togo & $\begin{array}{l}\text { French \& } \\
\text { Local Dialect }\end{array}$ & None & 12 years \\
\hline Rania & Female & $\begin{array}{l}\text { Saudi } \\
\text { Arabia }\end{array}$ & $\begin{array}{l}\text { Arabic \& Local } \\
\text { Dialect }\end{array}$ & None & 2 years \\
\hline Roger & Male & $\begin{array}{l}\text { Saudi } \\
\text { Arabia }\end{array}$ & $\begin{array}{l}\text { Arabic \& Local } \\
\text { Dialect }\end{array}$ & $\begin{array}{l}\text { One poetic autoethnography } \\
\text { assignment }\end{array}$ & 12 years \\
\hline Sarah & Female & Algeria & Arabic \& French & $\begin{array}{l}\text { One poetic autoethnography } \\
\text { assignment and personal interests }\end{array}$ & 11 years \\
\hline Thapelo & Male & $\begin{array}{l}\text { South } \\
\text { Africa }\end{array}$ & $\begin{array}{l}\text { Xitsonga \& Local } \\
\text { Dialects }\end{array}$ & $\begin{array}{l}\text { One poetic autoethnography } \\
\text { assignment and personal interests }\end{array}$ & 8 years \\
\hline Zak & Male & Japan & Japanese & None & 8 years \\
\hline
\end{tabular}

\subsection{Data analysis}

Content analysis was used in the process of data analysis. According to Hsieh and Shannon (2005), qualitative content analysis is the most common method to analyze the written data. They further defined the content analysis as "a research method for the subjective interpretation of the content of text coding through the systematic classification process of coding and identifying themes or patterns" (Hsieh \& Shannon, 2005, p. 1238). Moreover, content analysis was used to explore "human behavior" (Ary, Jacobs, \& Sorensen, 2010, p. 29). Overall, there are three stages of data analysis.

\subsubsection{Stage 1: Data preparation}

In this stage, 18 interviews were transcribed into written texts through transcription software with student names replaced by pseudonyms. The process of transcribing the verbal interview data into the written documents took a long time and needed high concentration to carefully translate participants' speech with minimal inaccuracy.

\subsubsection{Stage 2: Developing coding categories and Coding all the data}

In order to examine how 18 prospective ESL/EFL teachers perceive writing poetry in a second language, data was coded by themes through the lens of four categories adopted from Iida's (2012a) study (i.e., difficulty, value, emotion, and attitude), and it could be revealed in a word, a sentence or even a paragraph. While transcribing in the stage 1, I gained some ideas of overall themes from the data. Nevertheless, all the written documents were read carefully and marked with initial ideas for about subcategories for coding. After developing the initial coding system, I coded two written interviews and tested the coding categories to see if they were properly coded or categorized. It took several times to revise the coding categories until it was finalized. In order to yield a better reliability of the analysis, I invited two raters to validate the coding system. Intraclass correlation coefficient (ICC) for inter-rater 
reliability estimates and their 95\% confident intervals were calculated using SPSS statistical package version 24 based on a mean rating $(\mathrm{k}=3)$, absolute-agreement, 2 way mixed-effects model. Table 2 shows agreement across raters of $0.87(p<.001)$, which indicates a good reliability among all raters. After validating the coding system, 18 written documents were coded into their category. This process of coding requires me to be careful on the consistency of the coding system, so I checked the coding repeatedly to prevent from making mistakes.

Table 2. Intraclass Correlation Coefficient Among All Three Raters

\begin{tabular}{|lllllllll|}
\hline & \multirow{2}{*}{$\begin{array}{l}\text { Intraclass } \\
\text { Correlation }\end{array}$} & \multicolumn{5}{l}{ 95\% Confidence Interval } & \multicolumn{4}{l|}{ F Test with True Value 0 } \\
\cline { 2 - 8 } & Lower Bound & Upper Bound & Value & df1 & df2 & Sig \\
\hline Average Measures & .862 & .711 & .941 & 7.152 & 19 & 38 & .000 \\
\hline
\end{tabular}

\subsubsection{Stage 3: Draw conclusion from the coded data}

The aim of this stage is to find the themes and patterns among all the written interviews from 18 participants about their emotions, perspectives or understandings toward poetry writing. I went through all the coded data and created tables of the patterns found. After these steps, I presented the results from these coded data based on the 18 prospective ESL/EFL teachers' perceptions about writing poetry in a second language.

\section{Results}

There are four main categories in this coding system about the prospective ESL/EFL teachers' perception toward writing poetry in a second language: difficulty, value, emotion, and attitude. Table 3 demonstrates all categories and subcategories with examples from the transcribed interview data. Additionally, the names shown in the examples are presented with pseudonyms.

Table 3. Frequency of Participants' Responses about Poetry Writing in the Aspects of Difficulty, Value, Emotion, and Attitude ( $\mathrm{N}=18)$

\begin{tabular}{|c|c|c|c|}
\hline Category & Subcategory & Frequency & Example \\
\hline \multirow{6}{*}{$\begin{array}{l}\text { Difficulty of } \\
\text { Writing } \\
\text { Poetry in A } \\
\text { Second } \\
\text { Language }\end{array}$} & Vocabulary & $13 / 18(72 \%)$ & $\begin{array}{l}\text { Touch, sometimes you you're your emotion is you you don't have } \\
\text { the real words to express that the feeling you you wanna uhhh } \\
\text { express. (Joy) }\end{array}$ \\
\hline & $\begin{array}{l}\text { Features of } \\
\text { Poems }\end{array}$ & $\begin{array}{l}12 / 18 \\
(67 \%)\end{array}$ & $\begin{array}{l}\text { That was the challenge for me to come up with those figurative } \\
\text { using idiom, you know, metaphor. (Thapelo) }\end{array}$ \\
\hline & $\begin{array}{l}\text { Topic or Content } \\
\text { of the Poems }\end{array}$ & $\begin{array}{l}7 / 18 \\
(39 \%)\end{array}$ & $\begin{array}{l}\text { It's very difficult for me to develop the idea... because of the topic is } \\
\text { I mean uhmm I just hardly think about the question (poetry theme } \\
\text { assigned by the instructor). (Ember) }\end{array}$ \\
\hline & Self-Expression & $\begin{array}{l}4 / 18 \\
(22 \%)\end{array}$ & $\begin{array}{l}\text { Poetry is about emotions...I didn't know it's a good thing...[In] my } \\
\text { culture, it's a bad thing if you are a man or a guy express himself. } \\
\text { (Enzo) }\end{array}$ \\
\hline & $\begin{array}{l}\text { Organization or } \\
\text { Format of the } \\
\text { Poems }\end{array}$ & $\begin{array}{l}4 / 18 \\
(22 \%)\end{array}$ & $\begin{array}{l}\text { Another challenge was how how I'm going to make this poem short } \\
\text { straight to the point. (Thapelo) }\end{array}$ \\
\hline & $\begin{array}{l}\text { Lack of } \\
\text { Knowledge }\end{array}$ & $4 / 18$ & $\begin{array}{l}\text { Before coming to that course [poetry writing], uhh we didn't have } \\
\text { the proper, you know, uhh, education and and that was uhh major }\end{array}$ \\
\hline
\end{tabular}




\begin{tabular}{|c|c|c|c|}
\hline & $\begin{array}{l}\text { About Writing } \\
\text { Poetry }\end{array}$ & $(22 \%)$ & fact in our, you know, difficulty having to write poetry. (Charles) \\
\hline \multirow{6}{*}{$\begin{array}{l}\text { Value of } \\
\text { Writing } \\
\text { poetry in A } \\
\text { Second } \\
\text { Language }\end{array}$} & Self-Expression & $\begin{array}{l}13 / 18 \\
(72 \%)\end{array}$ & $\begin{array}{l}\text { I start writing [poetry] and sometimes like I don't wanna stop, I } \\
\text { really don't wanna stop. (Roger) }\end{array}$ \\
\hline & Self-Discovery & $\begin{array}{l}8 / 18 \\
(44 \%)\end{array}$ & $\begin{array}{l}\text { Poetry writing experience help(s) me to uncover something, which } \\
\text { was uh hidden inside me. (Joy) }\end{array}$ \\
\hline & $\begin{array}{l}\text { Therapeutic } \\
\text { Healing }\end{array}$ & $\begin{array}{l}6 / 18 \\
(33 \%)\end{array}$ & $\begin{array}{l}\text { When you write a poem, it frees you from some kind of inner pain } \\
\text { you are having. (Amir) }\end{array}$ \\
\hline & Language Skills & $\begin{array}{l}5 / 18 \\
(28 \%)\end{array}$ & $\begin{array}{l}\text { It [poetry writing] can be a strong uh tool, really for students to } \\
\text { learn to improve their literacy. (Amir) }\end{array}$ \\
\hline & $\begin{array}{l}\text { Writing } \\
\text { Ownership }\end{array}$ & $\begin{array}{l}4 / 18 \\
(22 \%)\end{array}$ & $\begin{array}{l}\text { In writing poetry, I mean you are the center...you are the author, } \\
\text { you own the you feel like you have ownership in that one, I don't } \\
\text { care people say right or not, but this is how I feel it is, this is how I } \\
\text { write my poems ...they [readers] cannot have any objections. } \\
\text { (Grace) }\end{array}$ \\
\hline & $\begin{array}{l}\text { Connecting with } \\
\text { Others }\end{array}$ & $\begin{array}{l}2 / 18 \\
(11 \%)\end{array}$ & $\begin{array}{l}\text { when you really write something in English and then you when } \\
\text { you share someone they said okay we experience the same thing } \\
\text { before. (Kelly) }\end{array}$ \\
\hline \multirow{5}{*}{$\begin{array}{l}\text { Emotion of } \\
\text { Writing } \\
\text { Poetry in A } \\
\text { Second } \\
\text { Language }\end{array}$} & Enjoyable/Free & $15 / 18(83 \%)$ & $\begin{array}{l}\text { They [poetry writing] permitted me to to open to a to say it, and to } \\
\text { it's kind of liberation, I free myself when I wrote. (Joy) }\end{array}$ \\
\hline & Confident & $\begin{array}{l}11 / 18 \\
(61 \%)\end{array}$ & $\begin{array}{l}\text { You can say it's revolutionist, because I didn't imagine that I can I } \\
\text { can I can do this (poetry writing). (Enzo) }\end{array}$ \\
\hline & Self-Doubting & $\begin{array}{l}9 / 18 \\
(50 \%)\end{array}$ & $\begin{array}{l}\text { I was asking myself that I don't think I will have the ability to do } \\
\text { that, and not being able to do that.... It means I'm not going to do } \\
\text { well in the class. (Thapelo) }\end{array}$ \\
\hline & Anxious & $\begin{array}{l}9 / 18 \\
(50 \%)\end{array}$ & $\begin{array}{l}\text { I was you know really scared that I don't know what I'm going to } \\
\text { do. (Charles) }\end{array}$ \\
\hline & Frustrated & $\begin{array}{l}4 / 18 \\
(22 \%)\end{array}$ & $\begin{array}{l}\text { I found I use I use that [the same vocabulary] in my poem, even } \\
\text { sometimes over } 6 \text { times, I'm terrible at and really terrible poetry } \\
\text { writer, I I feel kind of disappointed. (Kelly) }\end{array}$ \\
\hline \multirow{3}{*}{$\begin{array}{l}\text { Attitude of } \\
\text { Applying } \\
\text { Poetry } \\
\text { Writing in } \\
\text { ESL/EFL } \\
\text { Classrooms }\end{array}$} & Acceptance & $\begin{array}{l}14 / 18 \\
(78 \%)\end{array}$ & $\begin{array}{l}\text { I'm gonna teach part of the class, like creative writing, I wanna } \\
\text { like encourage my students to uhmm you know, be like proud of } \\
\text { themselves. (Roger) }\end{array}$ \\
\hline & Uncertainty & $\begin{array}{l}4 / 18 \\
(22 \%)\end{array}$ & $\begin{array}{l}\text { Until I know the teaching language through creative writing is } \\
\text { logic, is is sounding logical to me, or it's kind of uhh I believe in it, } \\
\text { or see how it work, at that time, yes [I will apply it]. (Bob) }\end{array}$ \\
\hline & Resistance & $\begin{array}{l}2 / 18 \\
(11 \%)\end{array}$ & $\begin{array}{l}\text { You have so little little to say about poetry writing, it's it's not as } \\
\text { important to uh to create a new course for. (Amanda) }\end{array}$ \\
\hline
\end{tabular}

As shown in Table 3, the difficulty of poetry writing is presented in various features. Thirteen participants (72\%) felt challenged in choosing vocabulary to express because of a lack of vocabulary. Moreover, 12 participants (67\%) encountered difficulties in meeting the features of poems, such as using rhymes or figurative language. Additionally, topic and the content of the poems are regarded as an issue, by seven participants (39\%), who stated that they faced certain struggles in coming up with themes for the topic. Interestingly, four participants revealed a difficulty to selfexpress their feelings in their writing, such as cultural taboo or personality. Another four participants (22\%) mentioned the difficulties of organizing their poems in terms of the format. Also, the lack of knowledge about writing poetry is one of the difficulties in experiencing poetry writing that four participants $(22 \%)$ pointed out. This data 
implies that the difficulties of poetry writing are focused more on the writing poetry itself, instead of personal or emotional factors.

Table 3 also gives the features of values in poetry writing from the participants' stances. Six concepts are presented. First, 13 participants (72\%) stated that the value of learning/teaching poetry writing is the improvement of self-expression. In addition, eight participants (44\%) mentioned self-discovery, in which they benefited from their poetry writing experiences or they expected to gain. Furthermore, therapeutic healing is regarded as one of the values for experiencing poetry writing; six participants (33\%) addressed that they had liberated themselves from some emotions or pressures during the process of poetry writing. Also, the improvement of language skills is another benefit that five participants (28\%) pointed out; they gained some knowledge in relation of linguistic or composition skills. Besides, four participants (22\%) stated the ownership of writing as a benefit of learning poetry writing, which they see themselves as writers or authors. Last, the value of connecting with others was addressed by two participants (11\%), who revealed that writing poetry and sharing them are rewarding and enjoyable. Overall, from the participants' perspectives, the two most frequent values of learning/teaching poetry writing are self-expression and self-discovery, in which one can express freely and understand one's self better.

Emotion is the third category shown in Table 3. Enjoyable/Free is the most frequent one in this category. Fifteen participants (83\%) addressed that they felt joy and freedom while experiencing poetry writing. Likewise, a sense of confidence was pointed out by 11 participants (61\%), in which they were proud of themselves. Moreover, nine participants (50\%) questioned their ability of accomplishing poetrywriting tasks. In addition, nine participants (50\%) felt anxious or nervous while they experienced the poetry writing. Also, four participants (22\%) found their poetry writing experiences were frustrating. To sum up, both negative and positive feelings are addressed among all the participants, but from the excerpts, it shows that the negative feelings existed mostly in the beginning of the writing tasks while positive emotions are presented both during and after the experiences. It entails the process of learning poetry writing starting from negative to positive feelings.

As for the attitude in this coding system, 14 participants (78\%) revealed their optimistic viewpoints toward learning and teaching poetry writing, concerning the importance and applicability of poetry writing. On the other hand, four participants (22\%) showed the indeterminate stance toward learning and teaching poetry writing in relation to the needs of knowing more information about poetry writing. Furthermore, two participants (11\%) confessed their disagreement or negative attitude toward poetry writing. In general, the majority of participants agree with the importance of learning or teaching poetry writing. For the group with uncertain attitudes, they showed the tendency of learning or teaching poetry writing if they acknowledge the need to utilize poetry writing in their teaching settings. As for the resisting group, the two participants believe that teaching academic writing skills is more important and the use of poetry writing is not able to meet the need. 


\section{Discussion}

This study's data suggests that prospective ESL/EFL teachers' perceptions mostly align with participants in Iida's (2012a) study. Iida investigated 20 EFL college students' perceptions toward haiku writing whereas this current study presented 18 prospective teachers' perceptions toward poetry writing. Both studies explored the data in four categories: difficulty, value, emotion, and attitude.

As shown in Table 4, for the difficulty aspect, there are some similarities between our studies-from Iida's (2012a) study, syllables (70\%), seasonal references (50\%), and in my study, features of poems (67\%), and organization or format of the poems $(22 \%)$. Also, participants on both studies view vocabulary as one main challenge. It is not surprising that understanding poetry conventions and having insufficient vocabulary are considered as prominent obstacles. When it comes to poetry, most people, including these ESL/EFL students, associate it with containing condensed forms, rhymes, and abstruse vocabulary. Besides this, remembering (15\%) is one difficulty for EFL students, which is parallel to topic or content of the poems (50\%) for prospective ESL/EFL teachers. This shows that both groups of participants encountered challenges in recalling events or reflecting their experiences when composing in a poetic form. Interestingly, both ESL students (65\%) and prospective ESL/EFL teachers (22\%) revealed difficulties in expressing emotions and opinions. Moreover, knowledge of poetry (22\%) from prospective teachers and previous learning experiences (30\%) from EFL students can be connected, in that both groups were not exposed to poetry writing in their past experiences. Thus, it can be inferred that these students were not given the opportunity to write poetry, to express emotions, or to examine their own life experiences in a more personal and meaningful manner. It seems that there are many shared perceived difficulties of writing poetry in a second language for both ESL students and prospective ESL/EFL teachers. These two sets of data are important because these described elements are potential causes for students to resist poetry writing instruction. With these factors in mind, teaches who are using or planning to utilize poetry writing can design lessons both to de-construct these perceived difficulties and to develop the skills needed.

Table 4. Comparison between EFL Students (Iida, 2012a) and Prospective ESL/EFL Teachers' Perception of Writing Poetry in a Second Language

\begin{tabular}{|l|l|l|l|l|}
\hline Category & $\begin{array}{l}\text { EFL Students } \\
(\mathrm{N}=20)\end{array}$ & $\begin{array}{l}\text { (Number) } \\
\text { Percentage }\end{array}$ & $\begin{array}{l}\text { Prospective EFL/EFL } \\
\text { Teachers (N=18) }\end{array}$ & $\begin{array}{l}\text { (Number) } \\
\text { Percentage }\end{array}$ \\
\hline Difficulty & Syllables & $(14) 70 \%$ & Vocabulary & $13 / 18(72 \%)$ \\
\cline { 2 - 5 } & Self-expression & $(13) 65 \%$ & Features of Poems & $12 / 18(67 \%)$ \\
\cline { 2 - 5 } & Seasonal references & $(10) 50 \%$ & Topic or Content of the Poems & $7 / 18(39 \%)$ \\
\cline { 2 - 5 } & Vocabulary & $(8) 40 \%$ & Self-Expression & $4 / 18(22 \%)$ \\
\cline { 2 - 5 } & $\begin{array}{l}\text { Previous learning } \\
\text { experiences }\end{array}$ & $(6) 30 \%$ & $\begin{array}{l}\text { Organization or } \\
\text { Format of the Poems }\end{array}$ & $4 / 18(22 \%)$ \\
\cline { 2 - 5 } & Remembering & $(3) 15 \%$ & Lack of Knowledge About Writing Poetry & $4 / 18(22 \%)$ \\
\hline Value & Vocabulary & $(17) 85 \%$ & Self-Expression & $13 / 18(72 \%)$ \\
\hline
\end{tabular}




\begin{tabular}{|c|c|c|c|c|}
\hline & & & Self-Discovery & $8 / 18(44 \%)$ \\
\hline & \multirow[t]{2}{*}{ Self-expression } & \multirow[t]{2}{*}{ (15) $75 \%$} & Therapeutic Healing & $6 / 18(33 \%)$ \\
\hline & & & Language Skills & $5 / 18(28 \%)$ \\
\hline & Applicability to other genres & (14) $70 \%$ & Writing Ownership & $4 / 18(22 \%)$ \\
\hline & Audience awareness & (6) $30 \%$ & Connecting with Others & $2 / 18(11 \%)$ \\
\hline \multirow[t]{5}{*}{ Emotion } & Interest & (11) $55 \%$ & Enjoyable/Free & $15 / 18(83 \%)$ \\
\hline & Sense of achievement & (10) $50 \%$ & Confident & $11 / 18(61 \%)$ \\
\hline & Surprise & (8) $40 \%$ & Self-Doubting & $9 / 18(50 \%)$ \\
\hline & Anxiety & (6) $30 \%$ & Anxious & $9 / 18(50 \%)$ \\
\hline & Reluctance & (2) $10 \%$ & Frustrated & $4 / 18(22 \%)$ \\
\hline \multirow[t]{3}{*}{ Attitude } & Acceptance & (14) $70 \%$ & Acceptance & $14 / 18(78 \%)$ \\
\hline & Resistance & (8) $40 \%$ & Unsureness & $4 / 18(22 \%)$ \\
\hline & Unsureness & (3) $15 \%$ & Resistance & $2 / 18(11 \%)$ \\
\hline
\end{tabular}

Table 4 also shows that there are more differences than similarities in terms of how students perceived the value of writing poetry in a second language. Self-expression is one value shared at a high percentage in the two studies, $75 \%$ and $72 \%$. Also, vocabulary (85\%) and applicability to other genres (70\%) are the values from the EFL students, which can be related to language skills (39\%) from the prospective teachers as an improvement in word knowledge and writing ability. Other than those, the result of Iida's study indicates that EFL haiku writing (i.e., audience awareness, 30\%) can bring readers to attention in writing processes. On the contrary, most statements that emerged from the prospective teachers group are more centered on writers' selfreflections during and after composing processes: self-discovery (44\%), therapeutic healing (33\%), writing ownership (22\%), and connecting with others $(11 \%)$. On the one hand, it is noteworthy that undergraduate EFL students associate the values of writing poetry in English with more feasible skills related to writing, which is in line with previous literature (see Hanauer, 2010; Tin, 2010). On the other hand, while prospective ESL/EFL teachers, advanced ESL students, acknowledge the feasible skills as the value, they are also able to recognize the intrapersonal, interpersonal, and affective development. These perceived values are addressed in existing literature, such as self-discovery, expressing emotion, or connect self-experiences with others (see Garvin, 2013; Hanauer, 2010, 2011; Iida, 2016b; Liao, 2016). These lines of research along with the current study indicate that ESL/EFL students are aware that they can benefit from writing poetry in a second language. However, further research is needed to examine the educational backgrounds in influencing ESL/EFL students' perceptions toward writing poetry in a second language.

Additionally, while Chamcharatsri (2013) touched upon the emotional aspect of writing poetry in a second language, he focused more on how EFL students perceive expressing emotions in their first and second language. So, the data of this current study contributes to the understanding of ESL students' emotional involvement when writing poetry in a second language. The emotion section of the data in my study finds harmony with Iida's (2012a) study. Obviously, the most frequent emotional feeling is the sense of involvement, which is shared in the EFL students (interest, 55\%) and 
prospective ESL/EFL teachers (enjoyable/free, 83\%). Their second most frequent feeling, sense of achievement or confidence, is consistent with slightly different rates (50\% and 61\%). As for negative emotions, EFL students are surprised (40\%) to the idea of writing haiku in a second language, which causes anxiety (30\%) so that they are reluctant (10\%) to compose the poems. Similarly, ESL/EFL prospective teachers tend to self-doubt (50\%) their own competence to write poetry in a second language, which involves sense of anxiety (50\%) or frustration (22\%). The two studies reported more negative emotional categories than positive ones; however, the negative feelings contain a lesser percentage rate compared to the positive ones. This entails that both EFL students and ESL/EFL prospective teachers considered writing poetry in a second language as a positive experience. For example, in my study, the sense of selfdoubt is only present in the beginning of the process and they gain the sense of confidence toward the end of the process. However, it needs more studies to investigate into the emotional aspect of writing poetry in a second language, such as indicators of positive and negative emotions.

For the last category, both Iida's (2012a) and my study presented three attitudes: acceptance, resistance and unsureness. As seen in Table 4, acceptance is the most frequent attitude for these two data sets, $70 \%$ for the EFL students and $78 \%$ for the prospective teachers. However, the second most frequent attitude varies. For Iida's study, the stance of resistance (40\%) is higher than unsureness (15\%), whereas, for my study, unsureness (22\%) is higher than resistance (11\%). It can be inferred that the difference is influenced by the roles of the participants: EFL university students and M.A. TESOL students who are teachers or prospective teachers. It seems that students tend to reveal their perceptions based on their personal experiences and feelings, but the teachers concern the applicability of poetry writing. However, this conclusion remains a hypothesis until further research with larger samples and statistic evaluation. What we can conclude now is that the stance of acceptance is much higher than the other two attitudes, which are less than $50 \%$ in both studies. Thus, overall, poetry and haiku writing are commonly and highly acceptable by both EFL students and prospective ESL/EFL teachers.

\section{Conclusion}

The aim of this study is to understand prospective ESL/EFL teachers' perceptions towards writing poetry in a second language in the aspects of difficulty, value, emotion, and attitude. While I am aware that the number of participants is limited and the discussion relies on interviews as the only data source, the study provides some understandings to the research inquiry on poetry writing in ESL/EFL contexts.

First, it is interesting that both EFL students and prospective teachers perceive higher percentages of positive emotions and the negative emotions are usually in the beginning of the writing process. This shows that there will be resistance and difficulty in bringing poetry writing instruction in language classrooms at the beginning, but the overall experiences are perceived positively. Also, both groups 
acknowledge the values of writing poetry in a second language. Their perceived values are in line with existing literature on the values of writing poetry (see Chamcharatsri, 2013; Garvin, 2013; Hanauer, 2010, 2015; Iida, 2012a, 2012b, 2016a, 2016b; Liao, 2016; Tin, 2010). Therefore, having resistance from students should not discourage poetry writing instruction in ESL/EFL classrooms.

Second, the need to uncover the practices in teaching poetry writing in ESL/EFL classrooms is an important issue to address. Matsuda and Friedrich (2011) indicated that "researchers have in general not engaged in profiling pedagogical ideas that are theoretically sounds, informed by research, and at the same time specific enough to be useful in classroom" (p. 333). That could be the reason why some teachers may have thoughts like one Chinese teacher in Burton's (2010) study. This Chinese teacher was at one secondary school in Hong Kong where two British teachers started a poetry-forpleasure project, and this teacher revealed his/her ideas toward teaching poetry writing in the following way:

But as I said just now, inner feeling is more important than the forms for poetry... The inspiration in culture is also very important, I think, if as a teacher I can also have inspiration with my colleagues. Because sharing, getting inspiration... how can I teach my students in an interesting way, and how can I inspire them to write a better poem? I think that should be a bigger question - for me. (Burton, 2010, p. 504)

As shown above, this reflects the data of the current study that some prospective teachers are uncertain about how to carry out poetry writing in their own classrooms. So, even if instructors like this Chinese teacher and the prospective teachers in this current study are aware of the value of teaching poetry writing, the struggle is how to teach it. Therefore, I propose the need for a professional development workshop or an M.A. TESOL course on the issues and ways of teaching poetry writing in ESL/EFL classrooms.

Last, the difficulties both EFL students and the prospective ESL/EFL teachers envisioned can invite language instructors to prepare how to tackle or avoid such struggles for our students, such as features of poetry, vocabulary, or self-expression. Therefore, we as ESL/EFL instructors can develop lessons in addressing or discussing the topics on syllables in writing haiku or on the concept of poetry with additional materials, such as a book of vocabulary in sounds words, imagery words, colors, etc. To further discuss how to solve these difficulties among teachers, professional development workshops or an M.A. TESOL course on the issues and ways of teaching poetry writing in ESL/EFL classrooms may be required. 


\section{References}

Ary, D., Jacobs, L. C., \& Sorensen, C. (2010). Introduction to research in education (8 ${ }^{\text {th }}$ edition). Belmont, CA: Cengage Learning.

Burton, P. (2010). Creativity in Hong Kong schools. World Englishes, 29(4), 493-507. doi/10.1111/j.1467-971X.2010.01677.x

Chamcharatsri, P. B. (2013). Poetry writing to express love in Thailand in English: A second language (L2) writing perspective. International Journal of Innovation in English Language, 2(2), 141-157.

Fernsten, L. (2008). Writer identity and ESL learners. Journal of Adolescent \& Adult Literacy, 52(1), 44-52. doi:10.1598/JAAL.52.1.5

Garvin, R. T. (2013). Researching Chinese History and Culture Through Poetry Writing in an EFL Composition Class. L2 Journal, 5(1), 76-94.

Hanauer, D. (2004). Poetry and the Meaning of Life. Toronto: Pippin.

Hanauer, D. I. (2010). Poetry as Research: Exploring second language poetry writing. Philadelphia: John Benjamins.

Hanauer, D. I. (2011). Meaningful literacy: Writing poetry in the language classroom. Language Teaching, 45(01), 105-115. doi:10.1017/S0261444810000522

Hanauer, D. I. (2014). Appreciating the beauty of second language poetry writing. In D. Disney (Ed.), Exploring second language creative writing: Beyond babel. (pp. 11-22). Philadelphia, PA: John Benjamins.

Hanauer, D. I. (2015). Measuring voice in poetry written by second language learners. Written Communication, 32(1), 66-86. doi: 10.1177/0741088314563023

Hsieh, H. F., \& Shannon, S. E. (2005). Three approaches to qualitative content analysis. Qualitative Health Research, 15(9), 1277-1288. doi: 10.1177/1049732305276687

Iida, A. (2008). Poetry writing as expressive pedagogy in an EFL context: Identifying possible assessment tools for haiku poetry in EFL freshman college writing. Assessing Writing, 13(3), 171-179. https://doi.org/10.1016/j.asw.2008.10.001

Iida, A. (2012a). Writing haiku in a second language: Perceptions, attitudes, and emotions of second language learners. Sino-US English Teaching, 9(9), 1472-1485.

Iida, A. (2012b). The value of poetry writing: Cross-genre literacy development in a second language. Scientific Study of Literature, 2(1), 60-82. doi: 10.1075/ssol.2.1.04iid

Iida, A. (2016a). Exploring earthquake experiences: A study of second language learners' ability to express and communicate deeply traumatic events in poetic form. System, 57, 120133. https://doi.org/10.1016/j.system.2016.02.004

Iida, A. (2016b). Poetic identity in second language writing: Exploring an EFL learner's study abroad experience. Eurasian Journal of Applied Linguistics, 2(1), 1-14.

Kramsch, C. (2003). The privilege of the nonnative speaker. In C. Blythe (Eds.), The sociolinguistics of foreign language classrooms: Contributions of the native, the near-native and the non-native speaker (pp.252-261). Boston: Heinle.

Liao, F. (2016). Identities in an ESL poetry book: A case study of one Chinese student. The Journal of Literature in Language Teaching, 5(1), 45-61.

Liao, F., \& Roy, S. (2017). EFL students' perceptions of writing poetry in English: The effect of educational backgrounds and belief towards poetry. The Journal of Literature in Language Teaching, 6(1), 55-72.

McKay, S. (2009). Teaching English as an International Language. New York: Oxford University Press. 
Matsuda, A., \& Friedrich, P. (2011). English as an international language: A curriculum blueprint. World Englishes, 30(3), 332-344. doi: 10.1111/j.1467-971X.2011.01717.x

Pennycook, A. (1996). Borrowing other's words: Text, ownership, memory, and plagiarism. TESOL Quarterly, 30(2), 201-230.

Tin, B. T. (2010). Language creativity and co-emergence of form and meaning in creative writing tasks. Applied Linguistics, 32(2), 215-235. https://doi.org/10.1093/applin/amq050 


\section{Appendix A. Interview Questions}

- Did you experience poetry writing during the years of learning English?

To participants who have the creative writing experiences:

1. If it was in a writing class, your professor tells you to write your own poetry, what will you think of this assignment?

2. What kinds of difficulties that you think you may face when writing poetry?

3. What do you think you will learn from writing poetry?

4. What elements do you think you will like about poetry writing?

5. What elements do you think you will dislike about poetry writing?

6. Do you think you are capable of writing poetry? Why?

To participants who have poetry writing experiences:

1. Please try to recall your memory when you heard that you were going to have a poetry writing assignment, what did you think of this assignment?

2. What kinds of difficulties did you face when writing your poetry?

3. What did you learn from the poetry writing experience?

4. What elements do you like about poetry writing?

5. What elements do you dislike about poetry writing?

6. Do you think you are capable of writing poetry? Why?

\section{Copyrights}

Copyright for this article is retained by the author(s), with first publication rights granted to the Journal.

This is an open-access article distributed under the terms and conditions of the Creative Commons Attribution license (CC BY-NC-ND) (http://creativecommons.org/licenses/by-nc-nd/4.0/). 